\title{
Association of rumination time and health status with milk yield and composition in early-lactation dairy cows
}

\author{
E. I. Kaufman, ${ }^{*}$ V. H. Asselstine, ${ }^{*}$ S. J. LeBlanc, $†$ T. F. Duffield, † and T. J. DeVries*1 \\ *Department of Animal Biosciences, and \\ †Department of Population Medicine, University of Guelph, 50 Stone Road East, Guelph, ON, N1G 2W1, Canada
}

\begin{abstract}
The objective of this study was to determine the associations of rumination time (RT) and health status with milk yield and milk composition. This study used 339 dairy cows from 4 commercial dairy farms in Ontario, Canada (first lactation, $\mathrm{n}=107$; second lactation, $\mathrm{n}=$ 112 ; $\geq$ third lactation, $\mathrm{n}=120)$. Rumination time was monitored $(24 \mathrm{~h} / \mathrm{d})$ using an automated system from 1 to $28 \mathrm{~d}$ in milk (DIM). Cows were milked $3 \times / \mathrm{d}$ on each farm, and 2 farms recorded milk weights at each milking to determine daily milk yield $(\mathrm{n}=170)$. Cows were also monitored for milk composition (fat and protein content) $1 \times /$ wk. Last, subclinical ketosis (SCK) was diagnosed $1 \times /$ wk; cows with at least one blood sample with $\beta$-hydroxybutyrate $\geq 1.2 \mathrm{mmol} / \mathrm{L}$ postcalving were diagnosed with SCK. Cases of retained placenta, metritis, milk fever, or mastitis during the study period were also recorded. Cows were categorized into 1 of 4 groups: healthy cows that had no SCK or any other health issue (HLT; $\mathrm{n}=139$ ); cows that were treated for at least one health issue other than SCK (HLT+; n $=50$ ); SCK cows with no other health problems during transition (HYK; $\mathrm{n}=97$ ); or cows that had SCK and one or more other health problems $(\mathrm{HYK}+; \mathrm{n}=$ 53). All data were summarized by week across cows, and the associations between rumination time and milk yield $(\mathrm{n}=170)$ and milk composition $(\mathrm{n}=339)$ were modeled. Across all lactations, and including all health categories, milk yield increased by week, whereas fat and protein content both decreased by week. A positive association was found between summarized RT and milk yield in first-lactation $(+0.006 \pm 0.003 \mathrm{~kg} / \mathrm{min}$ of RT) and second-lactation $(+0.015 \pm 0.004 \mathrm{~kg} / \mathrm{min}$ of RT) cows from 4 to 28 DIM, as well as in $\geq$ thirdlactation cows; however, the relationship between RT
\end{abstract}

Received March 21, 2017.

Accepted August 25, 2017.

${ }^{1}$ Corresponding author: tdevries@uoguelph.ca and milk yield differed across weeks in those cows. A negative association between RT and milk fat content was found in $\geq$ third-lactation cows $(-0.002 \pm 0.00059$ percentage points/min of RT). From 4 to 28 DIM, $\geq$ third-lactation HYK and HYK + cows produced less protein $(0.11 \pm 0.051$ and $0.13 \pm 0.056$ percentage points, respectively) than HLT cows. Over the 4-wk observation period, first-lactation HYK+ cows tended to deposit $0.11 \pm 0.056$ percentage points less protein in their milk compared with HLT cows. Second-lactation HYK+ cows produced less milk than HLT cows each week during early lactation. In summary, RT was positively associated with milk yield in early-lactation dairy cows, across all lactations, and negatively associated with milk fat content in $\geq$ third-lactation cows. Further, the results showed that early-lactation cows that experience SCK, particularly with one or more other health problems, might have decreased milk yield and milk protein content.

Key words: early lactation, rumination, behavior, ketosis

\section{INTRODUCTION}

Dairy cows are a foregut fermenting species and thus, rumination is a natural behavior. A proper ration should include adequate physically effective fiber (Kononoff et al., 2003a; Beauchemin and Yang, 2005) to stimulate regurgitation, remastication, and swallowing of boluses (Welch, 1982). The process of rumination increases the surface area of feed particles, making them more accessible to microbes, but it also stimulates saliva production to help buffer the rumen and create a homeostatic environment for microbes (Erdman, 1988; Allen, 1997). Rumination facilitates the passage of DM from the rumen through the gastrointestinal tract as particles are broken down. As passage rate increases, DMI increases in dairy cows (Nelson and Satter, 1992). Thus, based on the role that rumination plays in digestion and passage rate, it would be expected that rumination activity be related to feed intake in dairy cows (Clément et al., 2014). 
To date, rumination activity has been most consistently associated with intake of physically effective NDF (peNDF), which combines dietary particle length and dietary NDF content, and is directly related to chewing activity and rumination (Yang and Beauchemin, 2006a). As the level of peNDF increases in the diet, the cow is stimulated to ruminate more (Zebeli et al., 2012). There is less consistent association of rumination with overall DMI in dairy cows. Schirmann et al. (2012) found that cows spend more time ruminating about $4 \mathrm{~h}$ after periods of high feed intake but found no association across the day. Rumination time has, more recently, been found to be a significant but small contributor in a DMI prediction model (Clément et al., 2014).

Given that DMI is the primary driver of milk production (Bargo et al., 2002), rumination time (RT) may be relatable to milk yield and milk composition. In fact, Soriani et al. (2013) were able to identify a positive association between milk yield and RT. Further, rumination behavior could be a promising indicator to track metabolic conditions associated with a decrease in DMI (Soriani et al., 2012), such as subclinical ketosis (SCK). This metabolic condition is defined as an elevation of ketone bodies in the blood, specifically BHB concentration $\geq 1.2 \mathrm{mmol} / \mathrm{L}$ during the postcalving period, with the highest incidence occurring between 5 and 16 DIM (Geishauser et al., 1998; Oetzel, 2004; McArt et al., 2012). To generate energy, fatty acids are converted into ketone bodies and, as these metabolites accumulate in circulation, DMI further decreases, as ketone bodies increase satiety (Allen et al., 2009; Piantoni and Allen, 2015). Kaufman et al. (2016) recently demonstrated that cows diagnosed with SCK after calving ruminate less than healthy cows during the week before and the week after calving. While fatty acids are being mobilized, they may also be incorporated into milk fat (Van Haelst et al., 2008); therefore, it may be possible to use milk composition, specifically fat content of the milk, as a diagnostic tool for SCK. Other researchers have found that negative energy balance tends to increase milk fat content while decreasing milk protein content (Miettinen and Setälä, 1993; Nir Markusfeld, 2003). Related to that, increased milk fat:protein (FP) ratios are associated with negative energy balance and may be indicative of SCK (Grieve et al., 1986; Duffield et al., 1997; Jenkins et al., 2015).

The objective of this study was to determine associations of RT and health status (SCK) with milk yield and milk composition. We hypothesized that greater RT would be associated with greater milk yield. We also predicted that SCK would be associated with lower milk yield and higher milk fat due to an increase in circulating fatty acids during fat mobilization.

\section{MATERIALS AND METHODS}

This research was part of a larger study aimed at evaluating the efficacy of rumination monitoring for the early detection of SCK. As such, detailed descriptions of the methodology are presented in Kaufman et al. (2016). In summary, 339 dairy cows (first lactation, n $=107 ;$ second lactation, $\mathrm{n}=112 ;$ third lactation, $\mathrm{n}$ $=120)$ on 4 commercial dairy farms were monitored for daily RT and sampled once weekly for milk component analysis and SCK testing from 4 to 28 DIM. Daily milk yield data were collected on 2 of the 4 farms. All cows were housed in freestall facilities, milked in a parlor 3×/d (farm 1: 0300, 1100, and $1900 \mathrm{~h}$; farm 2: 0500, 1300, and $2100 \mathrm{~h}$; farm 3: 0500, 1300, and $2100 \mathrm{~h}$; farm 4: 0430, 1315, and $2115 \mathrm{~h}$ ), and fed a TMR 1×/d (farm 1: $0700 \mathrm{~h}$; farm 2: $0630 \mathrm{~h}$; farm 3: $0500 \mathrm{~h}$; farm 4: $0730 \mathrm{~h}$ ). The nutritional breakdown of each farm's fresh-cow TMR is described in Kaufman et al. (2016). Physically effective NDF was calculated (as per Yang and Beauchemin, 2006a) as (1) the proportion of DM retained by the 19- and 8-mm sieves of the Penn State Particle Separator (PSPS; Kononoff et al., 2003b) multiplied by dietary NDF content $\left(\operatorname{peNDF}_{>8}\right)$; and (2) the proportion of DM retained by 19-, 8-, and 1.18-mm sieves of the PSPS multiplied by dietary NDF content $\left(\mathrm{peNDF}_{>1.18}\right)$. The peNDF $>8$ for the fresh-cow ration on farms $1,2,3$, and 4 was 19.1, 15.3, 13.0, and 18.6, respectively. The peNDF $>1.18$ for the fresh-cow ration on farms 1, 2, 3, and 4 was 28.5, 25.2, 23.1, and 26.4, respectively. Animal use and study design were approved by the University of Guelph's Animal Care Committee (AUP\#2518) and Research Ethics Board (REB\#14JA015), respectively.

\section{Rumination Behavior}

As described by Kaufman et al. (2016), rumination activity was monitored $24 \mathrm{~h} / \mathrm{d}$ from 2 wk before calving until 4 wk after calving, using an electronic rumination detection system (Hi-Tag, SCR Engineers Ltd., Netanya, Israel), as validated by Schirmann et al. (2009). Each individual cow's rumination data were uploaded to the system at least once every $23 \mathrm{~h}$. The system recorded how many minutes the cow was ruminating per 2-h interval; the twelve 2 -h intervals were summed each day to create a daily RT.

\section{Determining Health Status}

Blood samples were collected from the coccygeal vein $1 \times /$ wk, and blood BHB concentration was measured in millimoles per liter using the Precision Xtra meter (Abbott Diabetes Care, Saint Laurent, QC, Canada), 
as validated by Iwersen et al. (2009). Blood samples were taken at the same time relative to feeding (2 to $6 \mathrm{~h}$ after feeding) each week on every farm. Cows were classified as being SCK when at least one BHB reading during the 4 -wk postcalving period was $\geq 1.2$ mmol/L (Geishauser et al., 1998; McArt et al., 2012). Producer-reported cases of retained placenta, metritis, milk fever, or mastitis during the study period were also recorded. Cows were categorized into 1 of 4 groups: cows that were not SCK and were not treated for any other health issue (HLT; total $\mathrm{n}=139$; first lactation, $\mathrm{n}=52$; second lactation, $\mathrm{n}=57$; $\geq$ third lactation, $\mathrm{n}=$ $30)$; cows that were not SCK but were treated for any other health issue $(\mathbf{H L T}+$; total $\mathrm{n}=50$; first lactation, $\mathrm{n}=20$; second lactation, $\mathrm{n}=13$; $\geq$ third lactation, $\mathrm{n}=$ 17); cows that were SCK but were not treated for any other health issue $(\mathbf{H Y K}$; total $\mathrm{n}=97$; first lactation, $\mathrm{n}=21$; second lactation, $\mathrm{n}=32$; $\geq$ third lactation, $\mathrm{n}$ $=44$ ); and cows that were SCK as well as treated for at least one other health issue $(\mathbf{H Y K}+$; total $\mathrm{n}=53$; first lactation, $\mathrm{n}=14$; second lactation, $\mathrm{n}=10$; $\geq$ third lactation, $\mathrm{n}=29$ ).

\section{Milk Production and Composition Data}

All participating farms milked $3 \times$ daily, and each weekly visit by researchers coincided with the milking schedule at each farm. Two of the 4 farms had on-site milk recording systems (farm 1: DeLaval milk meter MM27BC, DeLaval, Tumba, Sweden; farm 3: Metatron 12 milk meter, WestFalia, GEA Farm Technologies, Düsseldorf, Germany), which were used to record daily milk yield from 1 to 28 DIM for each sample cow in first lactation, $\mathrm{n}=49$ (HTL, $\mathrm{n}=23 ; \mathrm{HLT}+, \mathrm{n}=3 ; \mathrm{HYK}, \mathrm{n}$ $=16 ; \mathrm{HYK}+, \mathrm{n}=7$ ); second lactation, $\mathrm{n}=54$ (HTL, $\mathrm{n}=28 ; \mathrm{HLT}+, \mathrm{n}=7$; HYK, $\mathrm{n}=15 ; \mathrm{HYK}+, \mathrm{n}=4)$; and $\geq$ third lactation, $\mathrm{n}=67$ (HTL, $\mathrm{n}=13$; HLT,$+ \mathrm{n}$ $=6 ; \mathrm{HYK}, \mathrm{n}=32 ; \mathrm{HYK}+, \mathrm{n}=16)$. Milk yield data for sample cows was downloaded on farm 3 each week from the milk recording software (DairyPlan C21, GEA Farm Technologies). Milk yield data for sample cows on farm 1 was obtained from Herd Navigator software (ALPRO, DeLaval) at the end of the trial. Milk weights for the morning, afternoon, and evening milkings were summed to obtain daily milk yield; if data were missing at any milking due to technical problems, the milk yield for that day was reported as a missing value $(\mathrm{n}=487)$.

Milk sampling for milk component analysis was performed each week on all farms. During one milking, $1 \times /$ wk, researchers collected a composite milk sample $(10 \mathrm{~mL})$ from each sample cow using a milk meter (farm 1, DeLaval milk meter MM27BC, DeLaval; farms 2, 3, and 4, WB HI/Pullout, Tru-Test Ltd., Auckland, New Zealand). Milk samples were taken during the same milking time each week at each farm; this was the second (afternoon) milking of the day on farms 1 (1100 $\mathrm{h})$ and $3(1300 \mathrm{~h})$, and the first (morning) milking of the day on farms $2(0500 \mathrm{~h})$ and $4(0430 \mathrm{~h})$. All milk samples were stored in a cooler, on ice, until researchers returned to the laboratory, where samples were frozen at $-20^{\circ} \mathrm{C}$ for a minimum of $24 \mathrm{~h}$. The first milk sample was obtained at a minimum of 4 DIM to avoid sampling colostrum. Four milk samples were collected from each sample cow within 4 wk after calving (wk 1, $7 \pm 2.5$ DIM, mean $\pm \mathrm{SD}$; wk 2, $14 \pm 2.4$ DIM; wk 3, $21 \pm 2.3$ DIM; wk 4, $28 \pm 2.1$ DIM). Milk samples were sent to CanWest DHI (Guelph, ON, Canada) and analyzed for fat content (\%) and protein content (\%). Then, FP ratios were generated by dividing fat content of the milk sample by protein content.

\section{Statistical Analysis}

Before analyses, all data were screened for normality and outliers using the UNIVARIATE procedure of SAS (version 9.4; SAS Institute Inc., Cary, NC). Outliers (defined as those values $>1.5$ times the interquartile range above the third quartile or below the first quartile) were detected for milk fat $(\mathrm{n}=22)$ and milk protein $(\mathrm{n}=$ 20) content, and thus were excluded from the analyses. Statistical analyses were performed with SAS (version 9.4; SAS Institute Inc.) using cow within farm (milk yield analysis, $\mathrm{n}=170$; milk component analysis, $\mathrm{n}=$ $339)$ as the experimental unit. Daily milk yield $(\mathrm{kg} / \mathrm{d})$ and daily rumination time $(\mathrm{min} / \mathrm{d})$ were summarized by cow and week (wk 1, 4 to 10 DIM; wk 2, 11 to 17 DIM, wk 3, 18 to 24 DIM; wk 4, 25 to 31 DIM) such that these data aligned with the once-weekly sampling of milk components and testing of SCK. These data were analyzed in a general linear mixed model (MIXED procedure in SAS), treating week as a repeated measure. Because of differences in milk sampling times as well as nutrition and management between farms, we tested farm as a fixed effect in a preliminary analysis to determine whether there were farm-specific effects on rumination, milk yield, and milk components; no effect of farm was detected and thus farm was considered random for all analyses. Significance was declared at $P \leq$ 0.05 , and tendencies were reported if $0.05<P \leq 0.10$.

When analyzing RT, Kaufman et al. (2016) found a 3-way interaction between parity, health status, and week relative to calving. Because of this association, summarized RT and health status were not included in the same models.

To address our first objective, we individually associated RT and week with milk yield data $(\mathrm{n}=170)$, milk fat content $(\mathrm{n}=339)$, milk protein content $(\mathrm{n}=$ $339)$, and FP ratio $(\mathrm{n}=339)$ across all cows and health 
status categories. These models included the random effects of farm and cow within farm (accounting for repeated measures across weeks) and the fixed effects of parity, week, and RT. The interactions of parity with week and parity with RT, as well as the 3-way interaction of parity, week, and RT were considered. The covariance structure was unstructured, selected by best fit according to Schwarz's Bayesian information criterion. An interaction between RT and parity was found for milk yield $(P<0.001)$ and milk fat content $(P=0.01)$; thus, data from cows in first, second, and $\geq$ third lactation were analyzed separately. These separate models included the fixed effects of RT and week, with farm and cow within farm included as random effects. Two-way interactions were retained in the model if significant.

The next objective was to determine how milk yield $(\mathrm{n}=154)$, fat content $(\mathrm{n}=289)$, protein content $(\mathrm{n}=289)$, and FP ratio $(\mathrm{n}=289)$ varied between healthy cows and cows with SCK. Comparisons were made between HLT and HYK cows and between HLT and HYK + cows, respectively; HLT + cows were not considered in this analysis. Therefore, the models for the milk-related data included the random effects of farm and cow within farm (accounting for repeated measures across weeks) and the fixed effects of parity, health status, and week. Interactions of parity with week, and parity with health status, and 3-way interactions of parity, health status, and week were considered. The covariance structure was unstructured, selected by best fit according to Schwarz's Bayesian information criterion. For milk yield, a tendency $(P=0.08)$ for a 3-way interaction was found between parity, health status, and week. Further, for milk fat content, a tendency $(P=0.06)$ for a 2 -way interaction was found between parity and week. Thus, we opted to analyze the data from first-, second-, and $\geq$ third-lactation cows separately. These separate models included the fixed effects of health status and week, with farm and cow within farm included as random effects. The interaction between health status and week was also retained in the model if significant. Differences in milk yield, milk fat content, milk protein content, and FP ratio between health categories and weeks were compared using the least squares means procedure with the PDIFF option. The Tukey-Kramer method was used to adjust the probability of differences in milk-related data across the $4 \mathrm{wk}$.

\section{RESULTS AND DISCUSSION}

Over the 4-wk observation period, first-, second-, and $\geq$ third-lactation cows on farms 1 and 3, where milk yield data were collected, ruminated for $428 \pm 103.1$,
$464 \pm 110.9$, and $464 \pm 108.1 \mathrm{~min} / \mathrm{d}$, respectively. This falls within typical ranges reported in the literature (e.g., 340 to $540 \mathrm{~min} / \mathrm{d}$ : Kononoff et al., 2003a; Beauchemin and Yang, 2005; Yang and Beauchemin, 2006b). As expected, each lactation category had an increase in milk yield each week $(P<0.04)$ during early lactation. For first- and second-lactation cows, there was an association of milk yield with RT and week (Table 1). For every 30-min increase in daily RT, daily milk yield from 4 to 28 DIM increased by 0.18 $\pm 0.086 \mathrm{~kg} / \mathrm{d}(P=0.03)$ and $0.45 \pm 0.13 \mathrm{~kg} / \mathrm{d}(P<$ 0.001 ) for first- and second-lactation cows, respectively, as illustrated in Figure 1. For $\geq$ third-lactation cows, there was an interaction between $\mathrm{RT}$ and week $(P=$ 0.001); for every 30 -min increase in daily RT, milk yield increased by $1.19 \pm 0.17,1.45 \pm 0.18,0.98 \pm 0.20$, and $1.08 \pm 0.21 \mathrm{~kg} / \mathrm{d}$ during wk $1,2,3$, and 4 , respectively (Figure 2; Table 2). An increase in milk yield must be supported by an increase in DMI to support energy demand (Maekawa et al., 2002; Beauchemin et al., 2008), which may also explain the increase in RT (Clément et al., 2014). Using a similar system to monitor RT as in the present study, Soriani et al. (2013) observed a positive correlation between RT and milk yield in
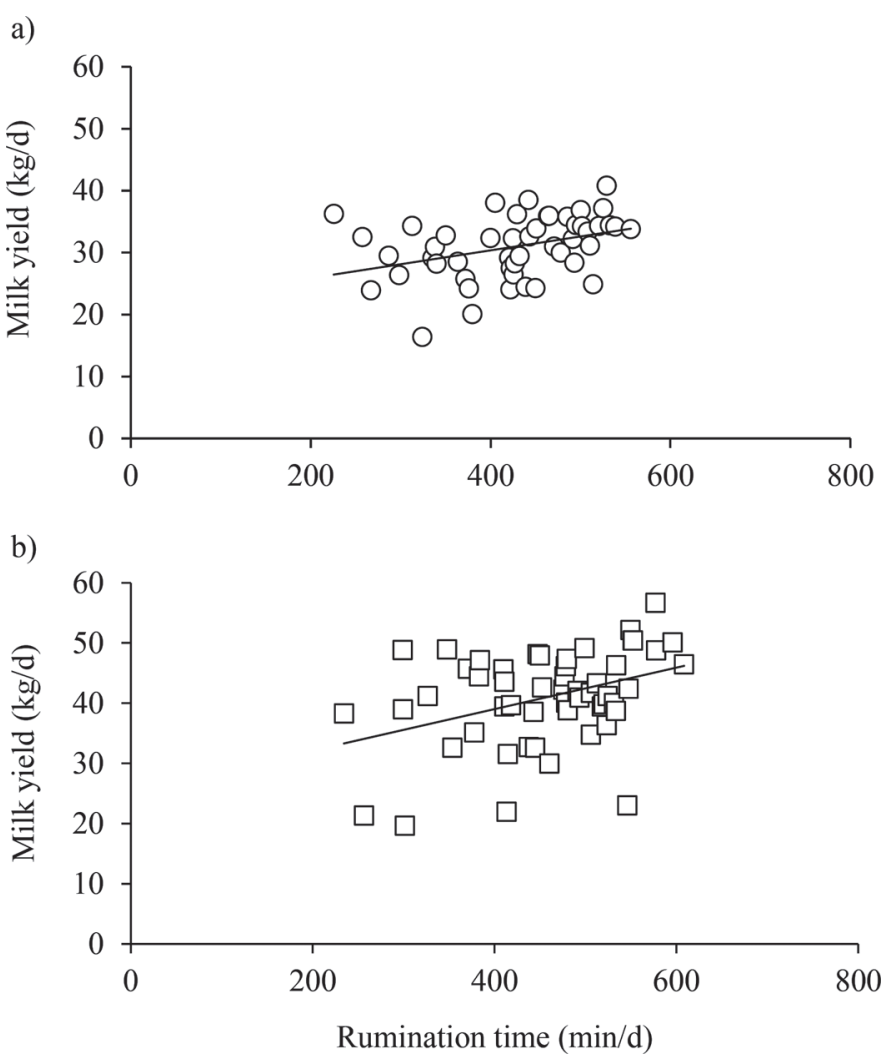

Figure 1. Scatterplot of summarized daily milk yield and daily rumination time from 4 to 28 DIM for dairy cows in (a) first ( $\mathrm{n}=49$, $\mathrm{r}=0.37)$ and $(\mathrm{b})$ second $(\mathrm{n}=54, \mathrm{r}=0.38)$ lactation. 
Table 1. Final general linear models for milk yield $(\mathrm{kg} / \mathrm{d})$ in first $(\mathrm{n}=49)$ and second $(\mathrm{n}=54)$ lactation cows from 1 to 28 DIM

\begin{tabular}{|c|c|c|c|}
\hline \multirow[b]{2}{*}{ Variable } & \multicolumn{3}{|c|}{ Milk yield $(\mathrm{kg} / \mathrm{d})$} \\
\hline & $\beta^{1}$ & SE & $P$-value \\
\hline \multicolumn{4}{|l|}{ First lactation } \\
\hline Intercept & 23.2 & 2.40 & 0.07 \\
\hline Rumination time (min/d) & 0.0061 & 0.00288 & 0.03 \\
\hline \multicolumn{4}{|l|}{ Week } \\
\hline $1^{2}$ & $\operatorname{Ref}^{3}$ & - & - \\
\hline $2^{4}$ & 4.6 & 0.34 & $<0.001$ \\
\hline $3^{5}$ & 7.5 & 0.52 & $<0.001$ \\
\hline $4^{6}$ & 9.7 & 0.66 & $<0.001$ \\
\hline \multicolumn{4}{|l|}{ Second lactation } \\
\hline Intercept & 27.9 & 2.19 & 0.05 \\
\hline Rumination time $(\mathrm{min} / \mathrm{d})$ & 0.015 & 0.00424 & $<0.001$ \\
\hline \multicolumn{4}{|l|}{ Week } \\
\hline 1 & Ref & - & - \\
\hline 2 & 5.9 & 0.66 & $<0.001$ \\
\hline 3 & 10.2 & 0.87 & $<0.001$ \\
\hline 4 & 12.4 & 1.08 & $<0.001$ \\
\hline
\end{tabular}

${ }^{1}$ Estimated regression coefficient.

${ }^{2} 7 \pm 2.5$ DIM (mean \pm SD).

${ }^{3}$ Ref $=$ reference value.

${ }^{4} 14 \pm 2.4$ DIM $($ mean $\pm \mathrm{SD})$.

${ }^{5} 21 \pm 2.3$ DIM (mean \pm SD).

${ }^{6} 28 \pm 2.1$ DIM (mean $\left.\pm \mathrm{SD}\right)$.

mid-lactation primiparous and multiparous cows. Similarly, a positive correlation between milk yield and RT was reported in early-lactation cows in several studies (Soriani et al., 2012; Calamari et al., 2014; Liboreiro et al., 2015). Although the literature reports correlations between these factors, no researcher, to our knowledge, has previously investigated whether this association varies by week and parity. Our research suggests that RT may be used to predict milk yield; however, future research is encouraged to explore this relationship further, along with the effects of other cow- and herd-level factors, to build a model that may predict milk yield in dairy cows.

Over the 4-wk observation period, first-, second-, and $\geq$ third-lactation cows across all 4 farms ruminated 442 $\pm 115.7,488 \pm 122.4$, and $488 \pm 108.4 \mathrm{~min} / \mathrm{d}$, respectively. Across all lactations, FP ratios did not vary by week. There was no association between rumination time and FP ratio in first- and second-lactation cows in early lactation; however, a negative association was observed in $\geq$ third-lactation cows (regression coefficient $\beta$ $\pm \mathrm{SE}=-0.00085 \pm 0.000186, P<0.01)$; this suggests that for every 30 -min decrease in daily RT, the FP ratio increased by 0.026 units. Increased FP ratios have been associated with SCK (Grieve et al., 1986; Duffield et al., 1997; Jenkins et al., 2015). Thus, this current association may reflect the finding of Kaufman et al. (2016) that multiparous cows with SCK ruminated less than healthy cows.
No association was found between milk protein content and RT $(P>0.1)$. Table 3 shows the individual associations of RT and week on milk fat content. A negative association between RT and milk fat content was found $(P=0.001)$ in $\geq$ third-lactation cows from 4 to 28 DIM; for every 30-min increase in daily RT, fat content decreased by $0.059 \pm 0.017$ percentage points (p.p.), as seen in Figure 3. As RT is higher in cows with higher milk yields, we hypothesized that cows with higher milk yield may have lower milk fat (Gaines and Davidson, 1923); in fact, in our study cows, we found a slight negative association between milk yield and milk fat content $(\mathrm{r}=-0.17, P=0.01)$. To our knowledge, there are no other reports of the association between milk components and RT in early-lactation dairy cows. Interestingly, in a study of mid-lactation Holstein and Swedish Red cows, Byskov et al. (2015) reported that rumination time (in $\mathrm{min} / \mathrm{kg}$ of DMI) was negatively associated with milk yield and milk protein percentage but positively associated with milk fat percentage. This difference in results compared with the current study likely arises from the stage of lactation of cows in the Byskov et al. (2015) study. Compared with mid-lactation cows, early-lactation cows would produce much more milk per unit of DM consumed and per minute of rumination resultant from that feed consumed.

Milk yield increased by week (Table 4) in all 3 parity categories. Comparing milk yield between parities, second-lactation cows produced the most milk on a 
Table 2. Final general linear models for milk yield $(\mathrm{kg} / \mathrm{d})$ in $\geq$ third lactation $(\mathrm{n}=67)$ cows during wk 1,2 , 3 , and 4

\begin{tabular}{lccc}
\hline & \multicolumn{3}{c}{ Milk yield $(\mathrm{kg} / \mathrm{d})$} \\
\cline { 2 - 4 } Model & $\beta^{1}$ & $\mathrm{SE}$ & $P$-value \\
\hline Wk $1^{2}$ & 13.8 & 2.82 & 0.13 \\
Intercept & 0.040 & 0.00555 & $<0.001$ \\
Rumination time (min/d) & & & 0.12 \\
Wk $2^{3}$ & 14.7 & 2.92 & $<0.001$ \\
Intercept & 0.048 & 0.00619 & 0.07 \\
Rumination time (min/d) & 26.1 & 3.062 & $<0.001$ \\
Wk $3^{4}$ & 0.033 & 0.00664 & 0.08 \\
Intercept & & & $<.23$ \\
Rumination time (min/d) & 27.1 & 0.00711 & $<0.001$ \\
Wk $4^{5}$ & 0.036 & & \\
Intercept & &
\end{tabular}

${ }^{1}$ Estimated regression coefficient.

${ }^{2} 7 \pm 2.5$ DIM (mean $\left.\pm \mathrm{SD}\right)$.

${ }^{3} 14 \pm 2.4$ DIM (mean $\left.\pm \mathrm{SD}\right)$.

${ }^{4} 21 \pm 2.3$ DIM (mean $\left.\pm \mathrm{SD}\right)$.

${ }^{5} 28 \pm 2.1$ DIM (mean $\left.\pm \mathrm{SD}\right)$.

daily basis followed by $\geq$ third-lactation cows and then first-lactation cows (Table 4). There is sufficient evidence that cows produce more milk with increasing parity (Lee and Kim, 2006); however, in the current study, $72 \%$ of the $\geq$ third-lactation cows were diagnosed with SCK, which is known to reduce milk production

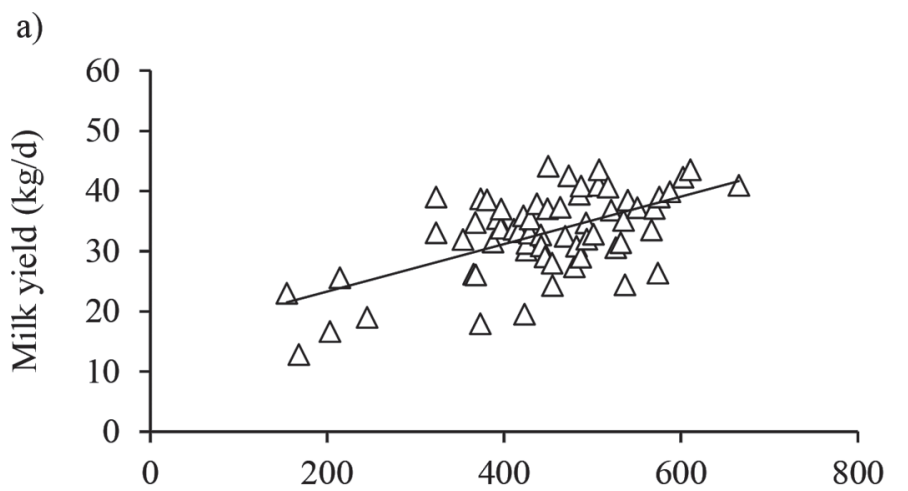

b)

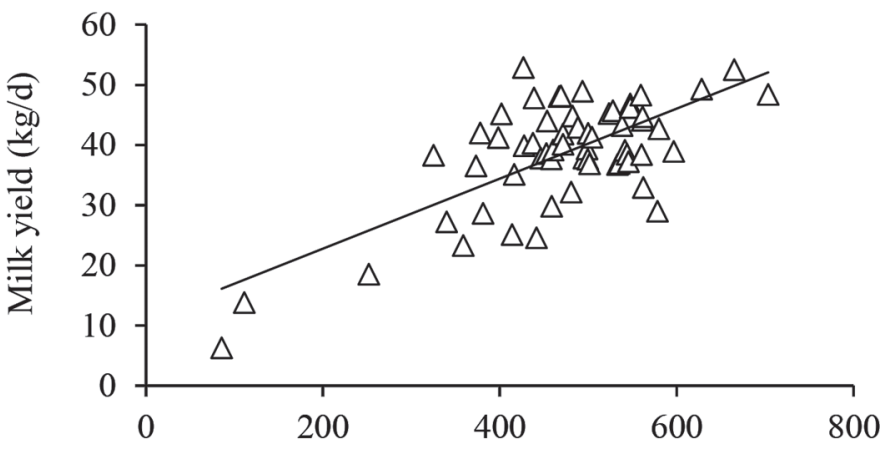

c)

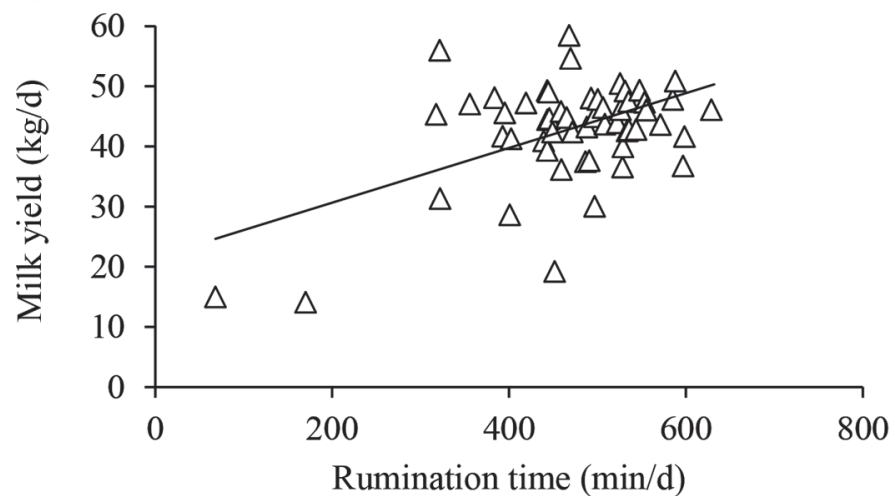

d)

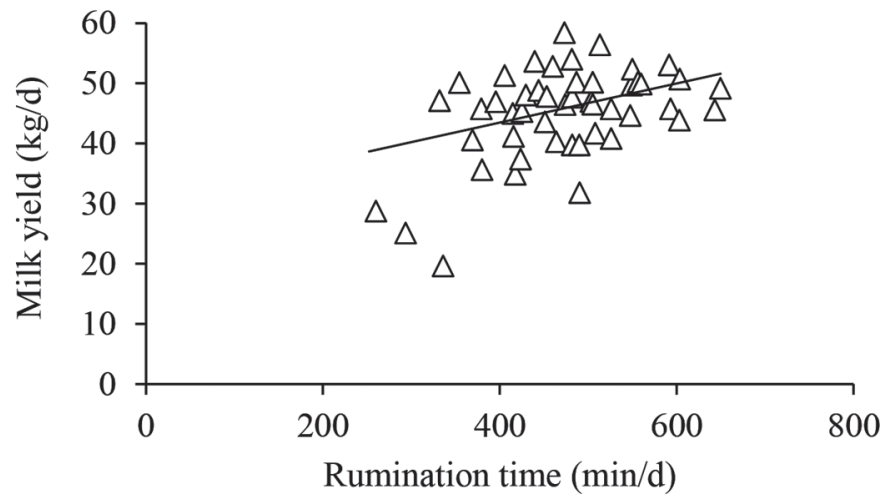

Figure 2. Scatterplot of daily milk yield and daily rumination time summarized by week for $\geq$ third lactation dairy $(\mathrm{n}=67)$ cows during (a) wk 1 ( $7 \pm 2.5$ DIM, mean $\pm \mathrm{SD}, \mathrm{r}=0.59)$, (b) wk $2(14 \pm 2.4 \mathrm{DIM}, \mathrm{r}=0.69)$, (c) wk $3(21 \pm 2.3, \mathrm{r}=0.52)$, and (d) wk 4 (28 $\pm 2.1 \mathrm{DIM}$, $\mathrm{r}=0.36)$ 
Table 3. Final general linear models for milk fat content sampled during 1 milking/wk for 4 wk (4-28 DIM) in first $(\mathrm{n}=107)$, second $(\mathrm{n}=112)$, and $\geq$ third $(\mathrm{n}=120)$ lactation cows

\begin{tabular}{|c|c|c|c|}
\hline \multirow[b]{2}{*}{ Variable } & \multicolumn{3}{|c|}{ Fat content $(\%)$} \\
\hline & $\beta^{1}$ & $\mathrm{SE}$ & $P$-value \\
\hline \multicolumn{4}{|l|}{ First lactation } \\
\hline Intercept & 4.5 & 0.37 & 0.001 \\
\hline Rumination time $(\mathrm{min} / \mathrm{d})$ & 0.0008 & 0.00056 & 0.15 \\
\hline \multicolumn{4}{|l|}{ Week } \\
\hline $1^{2}$ & $\operatorname{Ref}^{3}$ & - & - \\
\hline $2^{4}$ & -0.5 & 0.097 & $<0.001$ \\
\hline $3^{5}$ & -0.5 & 0.13 & $<0.001$ \\
\hline $4^{6}$ & -0.7 & 0.11 & $<0.001$ \\
\hline \multicolumn{4}{|l|}{ Second lactation } \\
\hline Intercept & 5.2 & 0.36 & 0.001 \\
\hline Rumination time $(\mathrm{min} / \mathrm{d})$ & -0.0005 & 0.00048 & 0.28 \\
\hline \multicolumn{4}{|l|}{ Week } \\
\hline 1 & Ref & - & - \\
\hline 2 & -0.4 & 0.10 & $<0.001$ \\
\hline 3 & -0.8 & 0.098 & $<0.001$ \\
\hline 4 & -0.8 & 0.13 & $<0.001$ \\
\hline \multicolumn{4}{|l|}{$\geq$ Third lactation } \\
\hline Intercept & 6.1 & 0.34 & $<0.001$ \\
\hline Rumination time $(\mathrm{min} / \mathrm{d})$ & -0.002 & 0.00059 & 0.001 \\
\hline \multicolumn{4}{|l|}{ Week } \\
\hline 1 & Ref & - & - \\
\hline 2 & -0.5 & 0.0962 & $<0.001$ \\
\hline 3 & -0.6 & 0.112 & $<0.001$ \\
\hline 4 & -0.8 & 0.14 & $<0.001$ \\
\hline
\end{tabular}

${ }^{1}$ Estimated regression coefficients.

${ }^{2} 7 \pm 2.5$ DIM (mean \pm SD).

${ }^{3}$ Ref $=$ reference value.

${ }^{4} 14 \pm 2.4$ DIM (mean $\left.\pm \mathrm{SD}\right)$.

${ }^{5} 21 \pm 2.3$ DIM (mean $\left.\pm \mathrm{SD}\right)$.

${ }^{6} 28 \pm 2.1$ DIM $($ mean $\pm \mathrm{SD})$.

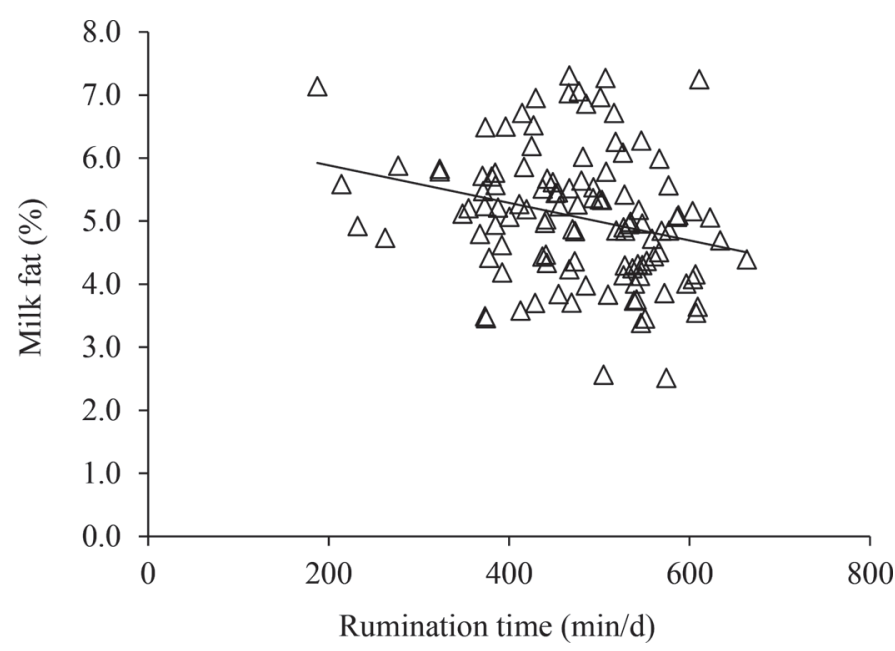

Figure 3. Scatterplot of milk fat composition and summarized daily rumination time for $\geq$ third lactation dairy cows $(\mathrm{n}=67, \mathrm{r}=$ $-0.27)$. Milk fat $(\%)$ was sampled during 1 milking/d $(1 \times /$ wk $)$ and daily rumination time $(\mathrm{min} / \mathrm{d})$ was summarized by week.
(Dohoo and Martin, 1984; Ospina et al., 2010; McArt et al., 2012). This may explain why these cows had lower milk yield compared with second-lactation cows.

Health status was not associated with milk yield for cows in their first or $\geq$ third lactation $(P \geq 0.3)$. In the current study, only a small number of first-lactation cows had SCK due to the overall sample size of the study (see sample size calculations described in Kaufman et al., 2016). If more first-lactation cows were sampled, increasing the number of cows in HYK and HYK+ groups, it may have been possible to detect differences between healthy and SCK cows in first lactation. In addition, there was a large proportion of SCK cows compared with healthy cows in the $\geq$ third-lactation category; therefore, it may have been difficult to detect differences in milk yield between health statuses in this lactation group.

We detected a 2-way interaction between health status and week $(P=0.01)$ associated with milk yield in second-lactation cows. On average, HLT cows in their second lactation produced $36.0 \pm 7.14$ (mean $\pm \mathrm{SD}$ ), $42.4 \pm 7.33,46.2 \pm 7.66$, and $49.4 \pm 8.43 \mathrm{~kg} / \mathrm{d}$, of milk, during wk 1, 2, 3, and 4, respectively. Second-lactation 
cows in HYK + produced less milk than HLT cows during wk $1(-7.1 \pm 2.9 \mathrm{~kg} / \mathrm{d}, P=0.02), 2(-14.2 \pm 4.0$ $\mathrm{kg} / \mathrm{d}, P<0.001), 3(-13.8 \pm 4.5 \mathrm{~kg} / \mathrm{d}, P=0.003)$, and $4(-10.6 \pm 5.3 \mathrm{~kg} / \mathrm{d}, P=0.05)$. As mentioned above, SCK is known to decrease milk yield in early lactation. When cows experience SCK, they generally decrease their feed intake, as ketone bodies promote satiety (Allen et al., 2009; Piantoni and Allen, 2015). This is supported by research from Goldhawk et al. (2009), who demonstrated that primiparous and multiparous cows diagnosed with SCK had a reduction in DMI and visited the feeder fewer times daily during the week before calving and 2 wk after.

Fat and protein contents of milk varied by week (Table 4). In all cows, protein content decreased each week during the study period. Milk fat content also declined moving from wk 1 to wk 2 for all cows, and decreased further by wk 4 in first- and second-lactation cows. Early-lactation cows in the current study had a higher milk fat and milk protein percentages (Table 4) compared with those of Koeck et al. (2013), who found that mean milk fat was $4.22 \%$ and milk protein was $3.16 \%$ in early-lactation (5-30 DIM) primiparous cows. Toni et al. (2011) assessed milk composition at 7 DIM and found milk fat to be much higher (5.2\%) compared with that at $\sim 40$ DIM (first DHIA test day, $3.5 \%$ fat). In very few studies has fat and protein content of milk been monitored in the first 4 wk of lactation. Our results show that fat and protein content decreased from wk 1 to wk 4 in all lactation categories, similar to the results of Toni et al. (2011). It is also possible that our measured component values were affected by the fact that milk was only sampled at 1 of the 3 daily milkings on each farm. Milk collected earlier in the day may be richer in fat than later milkings throughout the day; however, the absence of a farm effect on milk components suggests no difference between milk sampled in the morning versus that sampled midday. It would, however, be beneficial for future research on this subject to account for variability between milkings by sampling and averaging across all milkings per day.

We detected no difference in milk fat content between health categories $(P>0.1)$ in all lactation categories. Previous research found higher milk fat content in cows with SCK (Duffield et al., 1997; Duffield, 2000). In the current study, cows with SCK in second and $\geq$ third lactations did produce, on average, $0.2 \%$ more fat than HLT cows, but this difference was not statistically significant $(P \geq 0.2)$, possibly because of a lack of power, as described in Kaufman et al. (2016).

Over the 4-wk observation period, first-lactation HLT cows deposited $3.1 \pm 0.33 \%$ protein in their milk and HYK+ cows tended to deposit $0.11 \pm 0.056$ p.p. less protein than HLT cows $(P=0.1)$. Healthy cows in the $\geq$ third-lactation category produced $3.2 \pm 0.041 \%$ protein in their milk over the 4 -wk observation period; HYK and HYK + cows had lower milk protein content $(-0.11 \pm 0.051$ p.p., $P=0.03$; and $-0.13 \pm 0.056$ p.p., $P=0.02$, respectively) than HLT cows. There was a 2 -way interaction of health status and week $(P=0.04)$ on protein content for cows in their second lactation. During wk 1, 2, 3, and 4, second-lactation HLT cows deposited $3.6 \pm 0.049,3.2 \pm 0.044,3.0 \pm 0.043$, and 2.9 \pm 0.045 p.p., respectively. During wk 2 and 3 , secondlactation HYK cows had lower milk protein content $(-0.08 \pm 0.043$ and $-0.12 \pm 0.041$ p.p, respectively; $P$ $\leq 0.05)$ and during wk 4 tended to produce less protein $(-0.08 \pm 0.045$ p.p; $P=0.08)$ compared with HLT

Table 4. Least squares means $\left( \pm\right.$ SE) for milk yield ${ }^{1}(n=154)$, milk fat content ${ }^{2}(n=289)$, and milk protein content ${ }^{3}(n=289)$ for cows in each lactation category during the first 4 wk of lactation

Period (relative to calving)

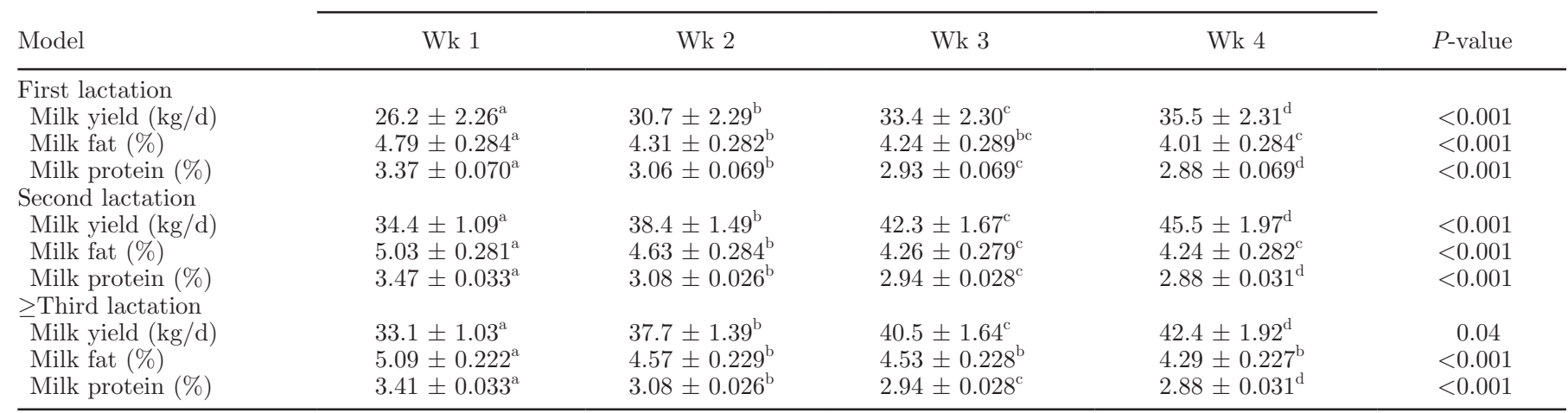

\footnotetext{
${ }^{\mathrm{a}-\mathrm{d}}$ Variable means within row with different superscripts differ $(P<0.05)$.

${ }^{1}$ Milk yield was recorded at each milking $(3 \times / \mathrm{d})$ and summed to determined daily milk yield.

${ }^{2}$ Milk fat was recorded during 1 milking/d, $1 \times /$ wk.

${ }^{3}$ Milk protein was recorded during 1 milking/d, $1 \times /$ wk.
} 
cows. Hyperketonemic cows with at least one other health issue $(\mathrm{HYK}+)$ during second lactation also had lower milk protein content compared with HLT cows in wk 1 , and $2,(-0.14 \pm 0.068$ and $-0.20 \pm 0.089$ p.p., respectively; $P \leq 0.05$ ). These decreases in milk protein content associated with SCK are consistent with those reported in the literature (Miettinen and Setälä, 1993; Miettinen, 1994). A positive association between net energy balance and milk protein content is well established; therefore, cows with SCK in negative energy balance have reduced milk protein content (Grieve et al., 1986; Duffield, 2000).

Health status did not affect the FP ratio of firstlactation cows, which averaged $1.43 \pm 0.089$ from 4 to 28 DIM. We did observe a health status effect in both second- and $\geq$ third-lactation cows. Healthy, HYK, and HYK + second-lactation cows had FP ratios of $1.40 \pm$ $0.095,1.51 \pm 0.099$, and $1.50 \pm 0.115$, respectively; FP ratio was only statistically higher in HYK compared with HLT cows $(P=0.01)$. Cows in their $\geq$ third lactation with HYK had higher FP ratios $(1.56 \pm 0.080, P$ $=0.03)$ and cows with HYK + tended to have higher $\mathrm{FP}$ ratios $(1.54 \pm 0.085, P=0.08)$ compared with HLT cows $(1.43 \pm 0.084)$. The FP ratios observed in this study are comparable to those seen in Jenkins et al. (2015), who found an average FP ratio of 1.64 in cows between 8 and 30 DIM. Multiple researchers have investigated various FP ratio cutoffs to diagnose SCK (Duffield et al., 1997; Jenkins et al., 2015). Although those researchers found an association between FP ratios and SCK similar to that in the current study, FP ratios may not be ideal for diagnosing SCK, due to a lack of a reported cutoff with both high sensitivity and specificity. As such, FP ratios may at best be a useful screening tool to help identify early-lactation cows that should be tested for SCK.

\section{CONCLUSIONS}

Rumination time was found to be positively associated with milk yield in early-lactation dairy cows, across all parities. Further, RT was found to be negatively associated with fat composition and FP ratios in $\geq$ thirdlactation cows. This provides evidence to support the use of RT as a predictor for milk yield; however, further research is needed to create and validate such a predictor model and determine how this model changes over lactation. Milk yield was lower in second-lactation cows with SCK and at least one other health problem compared with healthy cows. Finally, we found that cows with SCK in early lactation have reduced milk protein content compared with healthy cows across all lactations.

\section{ACKNOWLEDGMENTS}

We thank all participating farms for allowing us to collect data on their herds. We are grateful to Robin Crossley, Lisa Gordon, Morgan Overvest, Caylie Corvinelli, and Hannah Gillespie of the University of Guelph, Kemptville Campus (Kemptville, ON, Canada) for all their technical help during data collection. Financial support for this research was received from the Natural Sciences and Engineering Research Council (Ottawa, ON, Canada), as well as from the Ontario Ministry of Agriculture Food University of Guelph Research Partnership (Guelph, ON, Canada). We thank Karen Beauchemin of Agriculture and Agri-Food Canada (Lethbridge, AB, Canada) for providing rumination monitoring equipment, as well as EastGen (Guelph, ON, Canada), particularly Mark Carson, for contributions towards the rumination monitoring equipment and technical support. Last, we thank Heather McDermit, Dan Dulmage, and Harold Thompkins from CanWest DHI (Guelph, ON, Canada) for allowing us to utilize the milk meters for this study.

\section{REFERENCES}

Allen, M. S. 1997. Relationship between fermentation acid production in the rumen and the requirement for physically effective fiber. J. Dairy Sci. 80:1447-1462.

Allen, M. S., B. J. Bradford, and M. Oba. 2009. Board-Invited Review: The hepatic oxidation theory of the control of feed intake and its application to ruminants. J. Anim. Sci. 87:3317-3334.

Bargo, F., L. D. Muller, J. E. Delahoy, and T. W. Cassidy. 2002. Performance of high producing dairy cows with three different feeding systems combining pasture and total mixed rations. J. Dairy Sci. 85:2948-2963.

Beauchemin, K. A., L. Eriksen, P. Nørgaard, and L. M. Rode. 2008. Salivary secretion during meals in lactating dairy cattle. J. Dairy Sci. 91:2077-2081.

Beauchemin, K. A., and W. Z. Yang. 2005. Effects of physically effective fiber on intake, chewing activity, and ruminal acidosis for dairy cows fed diets based on corn silage. J. Dairy Sci. 88:2117-2129.

Byskov, M. V., E. Nadeau, B. E. O. Johansson, and P. Nørgaard. 2015. Variations in automatically recorded rumination time as explained by variations in intake of dietary fractions and milk production, and between-cow variation. J. Dairy Sci. 98:3926-3937.

Calamari, L., N. Soriani, G. Panella, F. Petrera, A. Minuti, and E. Trevisi. 2014. Rumination time around calving: An early signal to detect cows at greater risk of disease. J. Dairy Sci. 97:3635-3647. http://dx.doi.org/https://doi.org/10.3168/jds.2013-7709.

Clément, P., R. Guatteo, L. Delaby, B. Rouillé, A. Chanvallon, J. M. Philipot, and N. Bareille. 2014. Short communication: Added value of rumination time for the prediction of dry matter intake in lactating dairy cows. J. Dairy Sci. 97:6531-6535.

Dohoo, I. R., and S. W. Martin. 1984. Subclinical ketosis: Prevalence and associations with production and disease. Can. J. Comp. Med. 48:1-5.

Duffield, T. F. 2000. Subclinical ketosis in lactating dairy cattle. Vet. Clin. North Am. Food Anim. Pract. 16:231-253.

Duffield, T. F., D. F. Kelton, K. E. Leslie, K. D. Lissemore, and J. H. Lumsden. 1997. Use of test day milk fat and milk protein to detect subclinical ketosis in dairy cattle in Ontario. Can. Vet. J. 38:713-718. 
Erdman, R. A. 1988. Dietary buffering requirements of the lactating dairy cow: A review. J. Dairy Sci. 71:3246-3266.

Gaines, W. L., and F. A. Davidson. 1923. Relation between percentage fat content and yield of milk: Correction of milk yield for fat content. Agriculture Experiment Station, University of Illinois, Urbana.

Geishauser, T., K. Leslie, D. Kelton, and T. Duffield. 1998. Evaluation of five cowside tests for use with milk to detect subclinical ketosis in dairy cows. J. Dairy Sci. 81:438-443.

Goldhawk, C., N. Chapinal, D. M. Veira, D. M. Weary, and M. A. G. von Keyserlingk. 2009. Prepartum feeding behavior is an early indicator of subclinical ketosis. J. Dairy Sci. 92:4971-4977.

Grieve, D. G., S. Korver, Y. S. Rijpkema, and G. Hof. 1986. Relationship between milk composition and some nutritional parameters in early lactation. Livest. Prod. Sci. 14:239-254.

Iwersen, M., U. Falkenberg, R. Voigtsberger, D. Forderung, and W. Heuwieser. 2009. Evaluation of an electronic cowside test to detect subclinical ketosis in dairy cows. J. Dairy Sci. 92:2618-2624.

Jenkins, N. T., G. Peña, C. Risco, C. C. Barbosa, A. Vieira-Neto, and K. N. Galvão. 2015. Utility of inline milk fat and protein ratio to diagnose subclinical ketosis and to assign propylene glycol treatment in lactating dairy cows. Can. Vet. J. 56:850-854.

Kaufman, E. I., S. J. LeBlanc, B. W. McBride, T. F. Duffield, and T. J. DeVries. 2016. Association of rumination time with subclinical ketosis in transition dairy cows. J. Dairy Sci. 99:5604-5618.

Koeck, A., F. Miglior, J. Jamrozik, D. F. Kelton, and F. S. S. Schenkel. 2013. Genetic associations of ketosis and displaced abomasum with milk production traits in early first lactation Canadian Holsteins. J. Dairy Sci. 96:4688-4696.

Kononoff, P. J., A. J. Heinrichs, and D. R. Buckmaster. 2003b. Modification of Penn State forage and total mixed ration particle separator and the effects of moisture content on its measurement. J. Dairy Sci. 86:1858-1863.

Kononoff, P. J., A. J. Heinrichs, and H. A. Lehman. 2003a. The effect of corn silage particle size on eating behavior, chewing activities, and rumen fermentation in lactating dairy cows. J. Dairy Sci. 86:3343-3353.

Lee, J. Y., and I. Kim. 2006. Advancing parity is associated with higher milk production at the cost of body condition and increase periparturient disorders in dairy herds. J. Vet. Sci. 7:161-166.

Liboreiro, D. N., K. S. Machado, P. R. B. Silva, M. M. Maturana, T. K. Nishimura, A. P. Brandão, M. I. Endres, and R. C. Chebel. 2015. Characterization of peripartum rumination and activity of cows diagnosed with metabolic and uterine diseases. J. Dairy Sci. 98:6812-6827.

Maekawa, M., K. A. Beauchemin, and D. A. Christensen. 2002. Effect of concentrate level and feeding management on chewing activities, saliva production, and ruminal $\mathrm{pH}$ of lactating dairy cows. J. Dairy Sci. 85:1165-1175.

McArt, J. A. A., D. V. Nydam, and G. R. Oetzel. 2012. Epidemiology of subclinical ketosis in early lactation dairy cattle. J. Dairy Sci. 95:5056-5066.

Miettinen, P. V. A. 1994. Relationship between milk acetone and milk yield in individual cows. Zentralbl. Veterinarmed. A 41:102-109.
Miettinen, P. V. A., and J. J. Setälä. 1993. Relationships between subclinical ketosis, milk production and fertility in Finnish dairy cattle. Prev. Vet. Med. 17:1-8.

Nelson, W. F., and L. D. Satter. 1992. Impact of stage of maturity and method of preservation of alfalfa on digestion in lactating dairy cows. J. Dairy Sci. 75:1571-1580.

Nir Markusfeld, O. 2003. What are production diseases and how do we manage them? Acta Vet. Scand. Suppl. 98:21-32.

Oetzel, G. R. 2004. Monitoring and testing dairy herds for metabolic disease. Vet. Clin. North Am. Food Anim. Pract. 20:651-674.

Ospina, P. A., D. V. Nydam, T. Stokol, and T. R. Overton. 2010. Associations of elevated nonesterified fatty acids and beta-hydroxybutyrate concentrations with early lactation reproductive performance and milk production in transition dairy cattle in the northeastern United States. J. Dairy Sci. 93:1596-1603.

Piantoni, P., and M. S. Allen. 2015. Evaluation of propylene glycol and glycerol infusions as treatments for ketosis in dairy cows. J. Dairy Sci. 98:5429-5439.

Schirmann, K., N. Chapinal, D. M. Weary, W. Heuwieser, and M. A. G. von Keyserlingk. 2012. Rumination and its relationship to feeding and lying behavior in Holstein dairy cows. J. Dairy Sci. 95:3212-3217.

Schirmann, K., M. A. G. von Keyserlingk, D. M. Weary, D. M. Veira, and W. Heuwieser. 2009. Technical Note: Validation of a system for monitoring rumination in dairy cows. J. Dairy Sci. 92:6052-6055.

Soriani, N., G. Panella, and L. Calamari. 2013. Rumination time during the summer season and its relationships with metabolic conditions and milk production. J. Dairy Sci. 96:5082-5094.

Soriani, N., E. Trevisi, and L. Calamari. 2012. Relationships between rumination time, metabolic conditions, and health status in dairy cows during the transition period. J. Anim. Sci. 90:4544-4554.

Toni, F., L. Vincenti, L. Grigoletto, A. Ricci, and Y. H. Schukken. 2011. Early lactation ration of fat and protein percentage in milk is associated with health, milk production, and survival. J. Dairy Sci. 94:1772-1783.

Van Haelst, Y. N. T., A. Beeckman, A. T. M. Van Knegsel, and V. Fievez. 2008. Short communication: Elevated concentrations of oleic acid and short chain fatty acids in milk fat of multiparous subclinical ketotic cows. J. Dairy Sci. 91:4683-4686.

Welch, J. G. 1982. Rumination, particle size and passage from the rumen. J. Anim. Sci. 54:885-894.

Yang, W. Z., and K. A. Beauchemin. 2006a. Physically effective fiber: Method of determination and effects on chewing, ruminal acidosis, and digestion by dairy cows. J. Dairy Sci. 89:2618-2633.

Yang, W. Z. and K. A. Beauchemin. 2006b. Effects of physically effective fiber on chewing activity and ruminal $\mathrm{pH}$ of dairy cows fed diets based on barley silage. J. Dairy Sci. 89:217-228.

Zebeli, Q., J. R. Aschenbach, M. Tafaj, J. Boguhn, B. N. Ametaj, and W. Drochner. 2012. Invited review: Role of physically effective fiber and estimation of dietary fiber adequacy in high-producing dairy cattle. J. Dairy Sci. 95:1041-1056. 